\title{
Defining product intake fraction to quantify and compare exposure to consumer products
}

\author{
Jolliet, Oliver; Ernstoff, Alexi; Csiszar, Susan A.; Fantke, Peter
}

Published in:

Environmental Science \& Technology (Washington)

Link to article, DOI:

10.1021/acs.est.5b01083

Publication date:

2015

Document Version

Publisher's PDF, also known as Version of record

Link back to DTU Orbit

Citation $(A P A)$ :

Jolliet, O., Ernstoff, A., Csiszar, S. A., \& Fantke, P. (2015). Defining product intake fraction to quantify and compare exposure to consumer products. Environmental Science \& Technology (Washington), 49, 89248931. https://doi.org/10.1021/acs.est.5b01083

\section{General rights}

Copyright and moral rights for the publications made accessible in the public portal are retained by the authors and/or other copyright owners and it is a condition of accessing publications that users recognise and abide by the legal requirements associated with these rights.

- Users may download and print one copy of any publication from the public portal for the purpose of private study or research.

- You may not further distribute the material or use it for any profit-making activity or commercial gain

- You may freely distribute the URL identifying the publication in the public portal 


\title{
Defining Product Intake Fraction to Quantify and Compare Exposure to Consumer Products
}

\author{
Olivier Jolliet, ${ }^{* \dagger}$ Alexi S. Ernstoff, ${ }^{\ddagger \dagger}$ Susan A. Csiszar, ${ }^{\dagger}$ and Peter Fantke ${ }^{* \dagger}$ \\ $\dagger$ Environmental Health Sciences \& Risk Science Center, School of Public Health, University of Michigan, Ann Arbor, Michigan \\ 48109-2029, United States
}

${ }^{\ddagger}$ Quantitative Sustainability Assessment Division, Department of Management Engineering, Technical University of Denmark, 2800 Kgs. Lyngby, Denmark

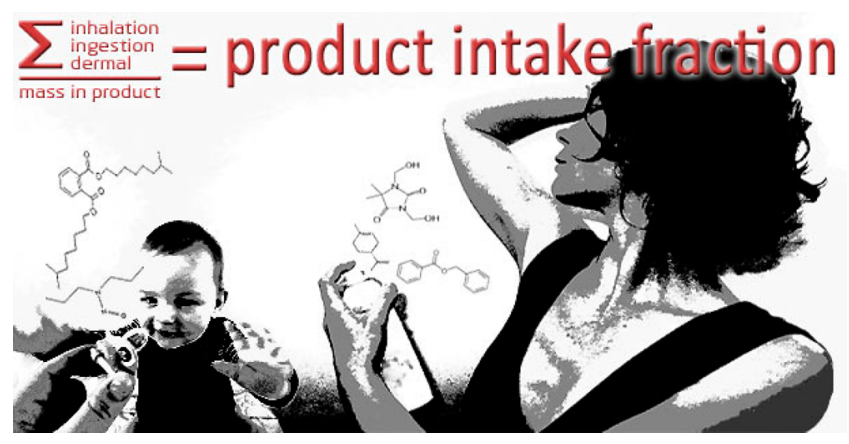

There is a growing consciousness that exposure studies need to better cover near-field exposure associated with products use. To consistently and quantitatively compare human exposure to chemicals in consumer products, we introduce the concept of product intake fraction, as the fraction of a chemical within a product that is eventually taken in by the human population. This metric enables consistent comparison of exposures during consumer product use for different product-chemical combinations, exposure duration, exposure routes and pathways and for other life cycle stages. We present example applications of the product intake fraction concept, for two chemicals in two personal care products and two chemicals encapsulated in two articles, showing how intakes of these chemicals can primarily occur during product use. We demonstrate the utility of the product intake fraction and its application modalities within life cycle assessment and risk assessment contexts. The product intake fraction helps to provide a clear interface between the life cycle inventory and impact assessment phases, to identify best suited sentinel products and to calculate overall exposure to chemicals in consumer products, or back-calculate maximum allowable concentrations of substances inside products.

\section{INTRODUCTION}

Every consumer product has the potential to expose humans to its chemical content during use and via subsequent environmental emissions. There is a growing consciousness that exposure studies used either in risk assessment (RA) or in life cycle assessment (LCA) need to cover both exposure to farfield ${ }^{1}$ environmentally mediated emissions and near-field ${ }^{1}$ direct dermal or indoor exposure during product use. ${ }^{2-5}$ Studies carried out on specific product-chemical combinations (e.g., phthalates in plastics, ${ }^{6}$ flame retardants in household products ${ }^{7}$ ) and indoor air exposures ${ }^{8-10}$ demonstrate that usestage exposure may exceed environmentally mediated exposures and is therefore essential to consider when assessing exposure to chemicals in products. ${ }^{11}$ It has been qualitatively understood for decades that the magnitude of near-field exposures is highly dependent on chemical properties, product characteristics, usage conditions, and user behavior. There is, hence, a need for a quantitative and comparative framework characterizing how specific product-chemical combinations differ in their potential for both near-field and environmentally mediated exposures. Several databases have recently become available for a first identification of such product-chemical combinations in terms of chemical occurrence and concentrations in products. ${ }^{12,13}$ The availability of these data needs to be complemented by a metric that enables comparison and ranking of the exposure magnitude across a wide range of product-chemical combinations. This metric should be applicable both in RA and LCA contexts to (a) compare orders of magnitude between different chemicals used in a given product and different product usages for a given chemical, (b) identify the key parameters influencing exposure and characterize its dependency on, for example, the product mass used or the exposure duration, (c) identify and compare predominant exposure pathways, (d) compare exposures occurring at different life cycle stages, ${ }^{14}$ while consistently differentiating near-field exposure from environmentally mediated exposures, and (e) facilitate the connection between the emission inventory and the impact assessment phase of an LCA.

In this paper, we aim to establish such a consistent comparative framework and metric characterizing how specific products differ in their chemical exposure potential. We provide a common basis to compare exposures to chemicals found in consumer products by (a) identifying an adequate point of departure, that is the best suited quantitative descriptor of chemical mass as a starting point for a product-oriented exposure assessment, (b) defining a new comparative exposure metric, the product intake fraction $(\mathrm{PiF})$, that is the chemical mass within a product eventually taken in by humans, (c) providing quantitative examples and demonstrating how PiF integrates into overall exposure frameworks, and (d) discussing the utility and limitations of $\mathrm{PiF}$ and its applicability for comparing exposures in LCA and RA contexts.

\section{POINTS OF DEPARTURE FOR COMPARING EXPOSURES TO CHEMICALS IN PRODUCTS}

Production volumes are available for various chemicals and have been proposed as a point of departure to determine product exposure. ${ }^{11}$ Nazaroff et al. ${ }^{15}$ defined the intake to production

Published: June 23, 2015 
Table 1. Comparison of Points of Departure and Metrics to Characterize Exposure to Chemicals

\begin{tabular}{|c|c|c|c|}
\hline point of departure & metric name & metric $^{b}$ & main assessment purpose and limitations \\
\hline $\begin{array}{l}\text { (a) total chemical } \\
\text { production volume }\end{array}$ & $\begin{array}{l}\text { intake to } \\
\text { production ratio }\end{array}$ & $\begin{array}{l}(\text { mass taken in }) / \\
\quad(\text { mass produced })\end{array}$ & $\begin{array}{l}\text { chemical delivery efficiency, difficult to characterize multiple product usages with widely } \\
\text { differing exposure pathways }\end{array}$ \\
\hline $\begin{array}{l}\text { (b) chemical mass } \\
\text { emitted to environment } \\
{ }^{16}\end{array}$ & $\begin{array}{l}\text { intake fraction } \\
\quad(\mathrm{iF})\end{array}$ & $\begin{array}{r}(\text { mass taken in }) / \\
(\text { mass emitted })\end{array}$ & $\begin{array}{l}\text { population-scale intakes due to environmental emissions, limited to emission-based } \\
\text { exposures }\end{array}$ \\
\hline $\begin{array}{l}\text { (c) chemical mass within } \\
\text { product }^{a}\end{array}$ & $\begin{array}{l}\text { product intake } \\
\text { fraction }(\mathrm{PiF})\end{array}$ & $\begin{array}{l}(\text { mass taken in }) / \\
\quad(\text { mass in product })\end{array}$ & $\begin{array}{l}\text { comparison of consumer intake of chemicals in products during use with population intake } \\
\text { resulting from product disposal, does not cover pre-use product life cycle stages (raw } \\
\text { material extraction, manufacturing) }\end{array}$ \\
\hline
\end{tabular}

${ }^{a}$ This study. "Mass taken in" is the same descriptor of "chemical mass taken in" in each of these metrics, but may correspond to different quantities depending on the considered point of departure.

ratio as an economy-wide quantitative indicator to assess the extent to which manufactured chemical production results in human exposure (Table 1a). While this metric is useful, it does not facilitate estimates of intake directly related to product use as production volumes do not easily allow differentiation between chemicals used as intermediary reactants in manufacturing from those used within objects and formulations. Additionally, the fractions of production volume used in each product type and population using these products are necessary to assess the intake to production ratio and are difficult to determine.

At the other end of the spectrum, chemical emissions can also constitute the point of departure for assessing exposure. Emissions are usually well-defined for exposure to substances released during the upstream production stages of a product life cycle (material extraction, chemical manufacturing, and product formulation) and related population-scale intakes are generally quantified by multiplying media-specific emissions by their respective intake fractions. Bennett et al. ${ }^{16}$ defined the intake fraction (iF) as the cumulated mass of a substance eventually taken in by a population divided by the mass emitted to the environment (Table 1b). This concept marked a shift in exposure assessment by introducing a consistent and transparent metric to assess intakes from environmental emissions. Recently, the iF concept has been extended to assess inhalation exposure to various substances emitted within indoor household ${ }^{2,8,9}$ and workplace environments, ${ }^{17,18}$ and for assessing ingestion exposure to pesticides via food consumption. ${ }^{19-21}$

There are, however, difficulties and inconsistencies when applying the emission-based $\mathrm{iF}$ to evaluate exposure to products, as some studies normalize human intake to the overall mass of product applied, ${ }^{2}$ while others normalize to the chemical mass volatilized and emitted from the product into the indoor environment. ${ }^{22,23}$ This inconsistency becomes problematic when studying chemicals that may lead to both dermal and inhalation exposures, such as fragrances in cosmetics or flame retardants in furniture. The resulting inhalation related $\mathrm{iF}$ for such scenarios is not directly comparable to the iF taken in via the skin, which should be normalized to the mass of product applied, not emitted. Therefore, the emission-based iF must be adapted to a consistent metric applicable for comparing exposures to chemicals in products.

During product use and disposal stages (Figure 1, orange boxes), chemicals in products are taken in via several use-stage

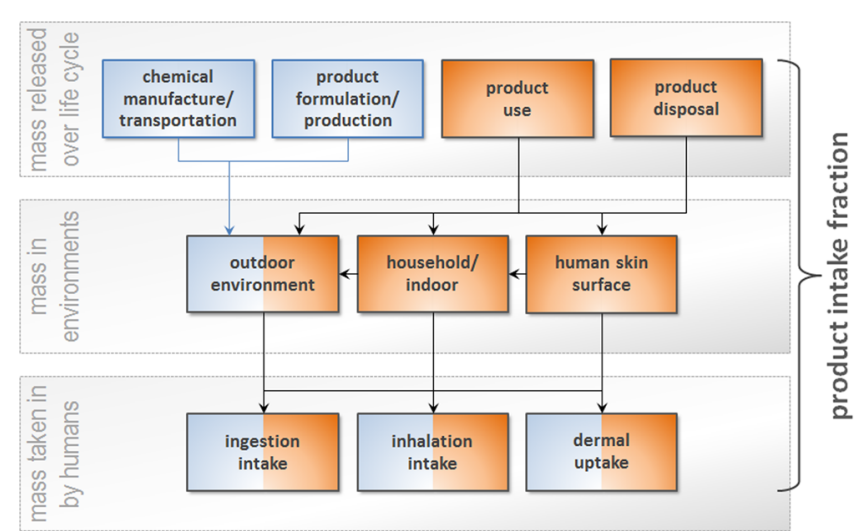

Figure 1. Exposure pathways for chemicals in products. Exposure to chemicals in products during product use and subsequent stages are shown in orange and exposure during upstream production stages in blue. Percentage orange or blue does not reflect actual percentage of exposure.

pathways depending on the product application mode and chemical properties, for example via direct dermal contact or indoor inhalation. Chemicals can also be taken in via subsequent environmentally mediated pathways associated with waste treatment and product disposal.

Additionally, the chemical mass in the product is a more appropriate point of departure than emissions or production volume to perform product-related exposure assessments. It is a stable, measurable quantity and only accounts for the fraction of the production volume that reaches the consumer and will eventually be disposed of with the product (Table 1c). It can also represent the quantity applied, for example for cosmetics and pesticides.

\section{DEFINING PRODUCT INTAKE FRACTION}

To quantify all the chemical intakes associated with the product use-stage and subsequent exposure pathways, we adapt the emission-based $\mathrm{iF}$ and define a new product-based metric termed product-chemical intake fraction, shortened here as the product intake fraction. PiF is defined as the chemical mass within a product eventually taken in by humans via all possible exposure pathways per unit of chemical mass within that product $\left(m_{c, p}, \mathrm{~kg}_{\text {in product }}\right)$ at the end of the manufacturing process, that is, starting at exposure time $t=0$ (Table 1c):

$$
P i F_{c, p, x}=\frac{\text { cumulative mass of chemical } c \text { in product } p \text { taken in by population via exposure pathway } x}{\text { initial mass of chemical } c \text { in product } p}=\frac{\int_{0}^{\infty} \partial I_{c, p, x}(t) / \partial t \mathrm{~d} t\left[\mathrm{~kg}_{\text {intake }}\right]}{m_{c, p}\left[\mathrm{~kg}_{\text {in product }}\right]}
$$

By default, PiF refers to a long-term, time-integrated exposure pathway-specific mass of a chemical in product taken in $\left(I_{c, p, x}, \mathrm{~kg}_{\text {intake }}\right)$; it includes the entire exposed population and must be calculated for all relevant exposure 
Table 2. Examples of Product Intake Fractions and Related Intakes Determined for Sodium Lauryl Ether Sulfate (SLES, CASRN 9004-82-4) and D-limonene (CAS-RN 138-86-3) in Two Personal Care Products, As Well As Diisononyl Phthalate (DINP, CAS-RN 28553-12-0) and Phenol (CAS-RN 108-95-2) in Two Consumer Articles, for Different Amounts Applied, Exposure Durations and Dominant Exposure Pathways

\begin{tabular}{|c|c|c|c|c|c|c|c|}
\hline chemical & $\begin{array}{l}\text { product-use } \\
\text { scenario }\end{array}$ & $\begin{array}{l}\text { amount of product used; \% } \\
\text { chemical content }\end{array}$ & $\begin{array}{l}\text { exposure } \\
\text { duration }\end{array}$ & $\begin{array}{c}\text { dominant exposure } \\
\text { pathway }\end{array}$ & $\begin{array}{c}\mathrm{PiF}^{\mathrm{use}} \\
\mathrm{kg}_{\text {intake }} / \mathrm{kg}_{\text {in product }}\end{array}$ & $\begin{array}{c}\mathrm{PiF}^{\text {disposal }} \\
\mathrm{kg}_{\text {intake }} / \mathrm{kg}_{\text {in product }}\end{array}$ & $\begin{array}{r}\text { chemical in } \\
\mathrm{mg}_{\text {intake }}\end{array}$ \\
\hline \multicolumn{8}{|c|}{ Chemicals in Personal Care Products ${ }^{a}$} \\
\hline SLES & $\begin{array}{l}\text { shampoo } \\
\text { average use }\end{array}$ & $5.05 \mathrm{~g}_{\text {product }} ; 20 \%$ & $0.065 \mathrm{~h}$ & $\underset{\text { dermal }^{a}}{\text { ingestion and }}$ & $4.5 \times 10^{-4}$ & $1.3 \times 10^{-4}$ & 0.6 \\
\hline \multirow{5}{*}{ D- } & $\begin{array}{l}\text { body lotion } \\
\text { average use }\end{array}$ & $8.7 \mathrm{~g}_{\text {product }} ; 20 \%$ & $12 \mathrm{~h}$ & dermal & 0.96 & $5.6 \times 10^{-6}$ & 1700 \\
\hline & $\begin{array}{l}\text { body lotion } \\
\text { high-end use }\end{array}$ & $27.9 \mathrm{~g}_{\text {product }} ; 20 \%$ & $12 \mathrm{~h}$ & dermal & 0.62 & $4.8 \times 10^{-5}$ & 3400 \\
\hline & $\begin{array}{l}\text { shampoo } \\
\text { average use }\end{array}$ & $5.05 \mathrm{~g}_{\text {product }} ; 0.5 \%$ & $0.065 \mathrm{~h}$ & dermal & 0.19 & $1.2 \times 10^{-5}$ & 4.8 \\
\hline & $\begin{array}{l}\text { body lotion } \\
\text { average use }\end{array}$ & $8.7 \mathrm{~g}_{\text {product }} ; 0.5 \%$ & $12 \mathrm{~h}$ & dermal & 0.19 & $1.2 \times 10^{-5}$ & 8.2 \\
\hline & $\begin{array}{l}\text { body lotion } \\
\text { high-end use }\end{array}$ & $27.9 \mathrm{~g}_{\text {product }} ; 0.5 \%$ & $12 \mathrm{~h}$ & dermal & 0.19 & $1.2 \times 10^{-5}$ & 26.5 \\
\hline \multirow{3}{*}{ DINP } & \multicolumn{7}{|c|}{ Chemicals Encapsulated in Articles } \\
\hline & $\begin{array}{l}b \text { pacifier } \\
\text { low-end use }\end{array}$ & $1.5 \mathrm{~g}_{\text {pacifier }} ; 40 \%$ & $45 \mathrm{~h}^{b}$ & mouthing & 0.009 & $1 \times 10^{-5}$ & 5.4 \\
\hline & $\begin{array}{l}\text { pacifier } \\
\text { high-end use }\end{array}$ & $1.5 \mathrm{~g}_{\text {pacifier }} ; 40 \%$ & $450 \mathrm{~h}^{b}$ & ingestion & 0.09 & $1 \times 10^{-5}$ & 54 \\
\hline \multirow[t]{2}{*}{ DINP } & $\begin{array}{l}1 \mathrm{~m}^{2} \text { flooring } \\
\text { thick } 5 \mathrm{~mm}\end{array}$ & $7500 \mathrm{~g}_{\text {flooring }} ; 20 \%$ & $15 \mathrm{a}$ & inhalation $^{c}$ & $5.8 \times 10^{-8}$ & $1 \times 10^{-5}$ & 0.05 \\
\hline & $\begin{array}{l}1 \mathrm{~m}^{2} \text { flooring } \\
\text { thin } 1.5 \mathrm{~mm}\end{array}$ & $2250 \mathrm{~g}_{\text {flooring }} ; 20 \%$ & $15 \mathrm{a}$ & inhalation & $1.9 \times 10^{-7}$ & $1 \times 10^{-5}$ & 0.05 \\
\hline \multirow[t]{3}{*}{ Phenol } & \multirow{3}{*}{$\begin{array}{l}1 \mathrm{~m}^{2} \text { flooring } \\
\text { thin } 1.5 \mathrm{~mm}\end{array}$} & \multirow[t]{3}{*}{$2250 \mathrm{~g}_{\text {flooring; }} ; 0.013 \%$} & $10 \mathrm{~d}$ & inhalation & $1.1 \times 10^{-3}$ & $<1 \times 10^{-10}$ & 320 \\
\hline & & & $100 \mathrm{~d}$ & inhalation & $3.5 \times 10^{-3}$ & $<1 \times 10^{-10}$ & 1030 \\
\hline & & & $15 \mathrm{a}$ & inhalation & $4.9 \times 10^{-3}$ & $<1 \times 10^{-10}$ & 1470 \\
\hline
\end{tabular}

${ }^{a}$ For shampoo, calculated using the model from Ernstoff et al. ${ }^{24}$ with application to head and hands surface area of $1598 \mathrm{~cm}^{2}$, dilution factor of 6 and skin permeation coefficient from Ten Berge. ${ }^{31}$ Body lotion calculation adapted from Ernstoff et al., ${ }^{24}$ with application to body area of $17000 \mathrm{~cm}^{2}$, dilution factor of $1 .{ }^{b} \mathrm{PiF}$ is calculated by multiplying the measured leaching rate of DINP out of plastic $\left(\left(1 \times 10^{-5} \mathrm{~g} / \mathrm{cm}^{2} / \mathrm{h}\right)\right.$, ${ }^{32-34}$ the mouthing contact area $\left(10 \mathrm{~cm}^{2}\right)^{35}$ and the contact duration over pacifier lifetime $\left(0.6\right.$ and $6 \mathrm{~h} / \mathrm{d}^{35}$ for 75 days yielding 45 and $450 \mathrm{~h}$, for low-end and high-end use, respectively). At the end of its use lifetime, the pacifier is disposed of in a landfill assuming $70 \%{ }^{36}$ leaching of the disposed DINP, multiplied by the population-scale USEtox ${ }^{26}$ outdoor air intake fraction. ${ }^{c}$ Flooring DINP and phenol releases calculated using Deng et al., ${ }^{28}$ respectively using diffusion coefficients of $1.33 \times 10^{-14}$ and $1.2 \times 10^{-13} \mathrm{~m}^{2} / \mathrm{s}$ as well as material-air partition coefficients of $1.9 \times 10^{12}$ and $1.2 \times 10^{5}$. Releases are combined with the indoor air intake fraction of 0.0049 calculated from Wenger et al. ${ }^{7}$ for a ventilation rate of $0.7 \mathrm{~h}^{-1}$ and a volume of $85 \mathrm{~m}^{3} / \mathrm{person}$, without indoor degradation. Abrasion and exposure from dust are not considered in this calculated PiF. At the end of its use lifetime, the pacifier is disposed of in a landfill assuming $70 \%^{36}$ leaching of the disposed DINP. Phenol is nearly entirely volatilized after 15 years.

pathways. It encompasses exposures associated with the usestage over the usable product lifetime and with waste treatment during or after product disposal.

\section{CALCULATION EXAMPLES AND INTEGRATION INTO EXPOSURE FRAMEWORKS}

Similar to the intake fraction, $\mathrm{PiF}$ does not replace an exposure assessment, but PiF enables us to characterize and compare the results of exposure assessments across a wide variety of product-chemical combinations, implying that either empirical data or near- and far-field exposure models are needed. Table 2 presents specific examples of PiFs calculated for two chemicals in two personal care products (PCPs: shampoo and body lotion), and two chemicals encapsulated in two articles (pacifier, flooring).

For chemicals in PCPs, PiF due to product use ( $\mathrm{PiF}^{\mathrm{use}}, \mathrm{kg}_{\text {intake }}$ ) $\mathrm{kg}_{\text {in PCP }}$ ) can be calculated using a dermal exposure model ${ }^{24}$ as a function of the chemical-specific skin permeation coefficient, the applied product layer thickness and exposure duration. This model takes into account dermal aqueous and gaseous uptake and inhalation exposure after volatilization. We adapted calculations originally applied to hair shampoo ${ }^{24}$ to body lotion, a commonly used leave-on product. For the surfactant sodium laurel ether sulfate (SLES, CAS-RN 9004-82-4), the PiFs in Table 2 vary substantially depending on exposure duration and product type from $6 \times 10^{-4}$ to 0.96 . In contrast, $\mathrm{PiF}$ is nearly constant for D-limonene (CAS-RN 138-86-3), since it is volatilized (81\%) and transferred dermally (19\%) within minutes. To include the contribution of product disposal, we estimated the PiF due to product waste disposal and treatment $\left(\mathrm{PiF}^{\text {disposal }}, \mathrm{kg}_{\text {intake }} / \mathrm{kg}_{\text {in PCP }}\right)$ assuming that the fraction of chemical not absorbed dermally nor volatilized was washed down the drain, transferred to a wastewater treatment plant (WWTP), and emitted to freshwater and soil from application of biosolids, ${ }^{25}$ from which environmentally mediated (emission-based) intake fractions were estimated with USEtox. ${ }^{26}$ For D-limonene, the resulting $\mathrm{PiF}^{\text {disposal }}$ of $10^{-5}$ is dominated by drinking water ingestion and is close to 4 orders of magnitude lower than the $\mathrm{PiF}^{\text {use }}$ of 0.19 . To evaluate the applied dermal exposure model, Csiszar et al. ${ }^{27}$ compared the PiF-based 
cumulative intake for several PCPs to biomarker data and found good agreement for parabens between modeled calculations and biomarker data.

For chemicals encapsulated in articles (e.g., toys, furniture, building materials), diisononyl phthalate (DINP, CAS-RN 28553-12-0) in pacifiers has sufficient empirical information to provide an example of measurement-based $\mathrm{PiF}$ for exposure via mouthing. PiF ${ }^{\text {use }}\left(\mathrm{kg}_{\text {intake }} / \mathrm{kg}_{\text {in pacifier }}\right)$ is the total mass of DINP that is ingested by the mouthing child during the overall mouthing time divided by the original DINP mass within the pacifier nipple. The ingested mass was estimated based on a measured DINP leaching rate out of plastic ${ }^{26-28}$ with the resulting $\mathrm{PiF}^{\text {use }}$ directly proportional to exposure duration and in the relatively high range of 0.01-0.1. In comparison, the population-scale $\mathrm{PiF}^{\text {disposal }}$ is close to $10^{-5}, 4$ orders of magnitude lower than the $\mathrm{PiF}^{\text {use }}$ of the individual child using the pacifier.

Chemicals encapsulated in flooring exemplify a less direct exposure pathway. We applied the Deng diffusion model ${ }^{28}$ to determine chemical releases from flooring and multiplied these by the indoor intake fraction ${ }^{7}$ to determine the $\mathrm{PiF}$ for a volatile organic compound (VOC, phenol) and a semivolatile organic compound (SVOC, DINP). The DINP releases from flooring lead to a PiF more than 6 orders of magnitude lower than from the pacifier, as SVOC releases from material are limited by the high material surface-air partitioning coefficient. The low PiF for SVOC volatilization implies for such small releases that abrasion of the material over the flooring lifetime may lead to substantially higher $\mathrm{PiF}$ than volatilization and deserves further attention. ${ }^{29}$ Compared to SVOCs, fractions volatilized from flooring are much higher for a VOC like phenol, as the VOC $\mathrm{PiF}$ approaches or equals the indoor inhalation intake fraction of $4.9 \times 10^{-3}$ ?

PiF Integration into Exposure Frameworks. The corresponding exposure pathway-specific intake, $I_{c, p, x}\left(\mathrm{~kg}_{\text {intake }}\right)$, can be calculated in a straightforward manner by multiplying the associated $\mathrm{PiF}\left(\mathrm{kg}_{\text {intake }} / \mathrm{kg}_{\text {in product }}\right)$ by the mass of product applied, $M_{\mathrm{p}}\left(\mathrm{kg}_{\text {product }}\right)$, and the chemical fraction in product, $f_{c, p}$ $\left(\mathrm{kg}_{\text {in product }} / \mathrm{kg}_{\text {product }}\right): I_{c, p, x}=\mathrm{PiF}_{c, p, x} \times M_{p} \times f_{c, p}$. Depending on the product-chemical combination, the resulting intake may be directly proportional to the mass of chemical applied (e.g., Dlimonene in PCPs, where $\mathrm{PiF}$ is fixed for most relevant application scenarios) and independent of exposure duration. $\mathrm{PiF}$ and intakes can also be proportional to exposure duration, for example for DINP in pacifiers and flooring, or a more complex function of exposure duration and mass applied with PiF saturation effects in the case of SLES in PCPs.

While the absolute chemical intake cannot be directly compared across various categories of products, $\mathrm{PiF}$ provides a directly comparable product usage perspective and population-based measure of the ability of product-chemical combinations to cause large intake doses in users per unit mass of chemical in product.

Identifying Factors of Influence and Plausible PiF Ranges Per Product Class. The examples in Table 2 show that the product-chemical specific PiF helps characterize the influence of the mode of entry in the near- or far-field environments. PiF will vary based on whether a chemical is directly embedded inside a product (e.g., furniture and clothing), released into the air (e.g., sprays and aerosols), applied on surfaces (e.g., cleaning products), or directly applied on the skin or ingested (e.g., cosmetics or food additives). For a given class of product, PiF-based sensitivity studies can identify the key parameters influencing exposure, be it the chemical properties, the location of use or the exposed population (e.g., density and proximity of room occupants). Throughout the past 15 years of research quantifying intake fractions (iF), ranges have been defined for specific exposure pathways (e.g., food chain ingestion due to emission to freshwater) and related to physicochemical properties (e.g., octanol-water and airwater partition coefficients $K_{\mathrm{ow}}$ and $K_{\mathrm{aw}}$ ), giving practitioners a developed intuition about plausible iF ranges. We anticipate a similarly useful outcome of using $\mathrm{PiF}$ in product-related exposure studies. As a first example, Ernstoff et al. ${ }^{24}$ investigated several possible chemicals in shampoo and found a generally restricted range of $\mathrm{PiF}$ due to use-stage dermal intake from $10^{-4}$ to $10^{-1}$, a much wider range of $\mathrm{PiF}$ due to usestage inhalation from $<10^{-10}$ to $10^{-1}$, and a restricted range of total intake due to environmentally mediated $\mathrm{PiF}$ around $10^{-4}$ to $10^{-5}$ dominated by various ingestion pathways.

Depending on study goals, $\mathrm{PiF}$ can also be used to compare exposure pathways and routes. For a given exposure route, $\mathrm{PiF}$ can be directly compared or added across various pathways, for example direct dermal application and subsequent dermal gaseous exchange of the volatilized fraction. ${ }^{30}$ Since subsequent exposure-responses may differ depending on route of exposure, it is useful to differentiate the PiF for each route.

Complementing Other Metrics. These examples also enable us to understand how the PiF relates and compares to the intake to production ratio and to the intake fraction metrics. Taking sodium lauryl ether sulfate (SLES) and diisononyl phthalate (DINP) as examples: these chemicals have very different physicochemical properties and are used in a wide variety of products, ranging from categories like personal care products (soap, body wash, shampoo) to laundry detergents for SLES and from floorings to electric wires for DINP. For such chemical-product combinations, the $\mathrm{PiF}$ can help support decision making on a per-product and per-chemical basis. In contrast, the overall intake to production ratio aggregates intakes over all products such that it is more difficult to disaggregate the individual source contributions for chemicals. To note, the PiF could be applied to calculate product-specific intake to production ratios in the rare instances data are available on the fraction of production volume used in every product type.

The intake fraction concept only applies to exposure pathways involving emissions to environmental compartments and is thereby not suited to estimate intakes occurring following direct application. The role of the $\mathrm{PiF}$ is to enable us to consistently combine various iFs (e.g., the inhalation iF for indoor releases from flooring or cosmetics, with the environmental iF from WWTP or landfill releases), with exposures occurring during product use not accounted for by $\mathrm{iF}$, such as direct dermal contact exposures.

We further discuss the utility and applicability of the PiF in the context of LCA as a functional product-oriented approach, and in the context of risk assessment as a receptor-oriented approach.

\section{UTILITY AND MODALITY OF APPLYING THE PRODUCT INTAKE FRACTION IN LIFE CYCLE ASSESSMENT AND RISK ASSESSMENT CONTEXTS}

Application in a Life Cycle Assessment Context, As a Product-Oriented Approach. To assess human health impacts, LCA first calculates life cycle inventory (LCI) flows usually reflecting resource extractions and environmental 
Table 3. Utility of the Product Intake Fraction for Comparing Various Exposure Dimensions

main utility-exposure comparison

comparison of product-chemical combinations

identification of key parameters influencing exposure

comparison of exposure routes and pathways

comparison of product life cycle stages

connection point to life cycle inventory analysis results

identification of best suited sentinel products

Forward and backward comparisons with $\mathrm{ADI}$ and OED key elements

mode of chemical entry into the near-field (e.g., encapsulated, sprayed, applied to surfaces or skin)

roles of product mass applied, exposure duration, chemical properties

inhalation (near person, indoor, outdoor), ingestion (hand to mouth, drinking, food), dermal (aqueous, gaseous)

use-stage, disposal-stage and upstream life cycle stages

mass of chemical in product per functional unit $\times \mathrm{PiF} \times$ effect factor

representative of a high-end exposure situation

key to define chemical usage and ranges of product chemical content application modalities

definition of plausible $\mathrm{PiF}$ ranges per product class contour plots, as a function of product and chemical properties

by default, inhalation, ingestion, and dermal $\mathrm{PiF}$ are kept separate for subsequent combination with toxicity data complementary role of $\mathrm{PiF}$ and of $\mathrm{iF}$ for upstream and downstream impacts

$\mathrm{PiF}$ as a product-oriented metric characterizes exposure to inproduct chemicals in LCA

sentinel products are used in large quantities, while maintaining a high $\mathrm{PiF}$

back-calculate maximum acceptable concentrations of substances inside products. emissions per a defined unit of product function, the "functional unit" (FU). For example, in the case of flooring the functional unit may be $1 \mathrm{~m}^{2}$ of standardized performance flooring used over 15 years, as a basis to compare different flooring materials. Though being product focused, most LCA studies have paradoxically neglected chemical intake during the product use-stage and primarily focused on exposure to chemicals emitted into environmental media (air, soil, water, etc.) during product manufacturing and disposal. ${ }^{26,37-41}$ To facilitate and extend LCA practices with an improved focus on chemical exposure during product use, in addition to the chemical emissions to the environment during raw material extraction and manufacturing stages, we suggest reporting an additional required LCI flow, that is, the mass of chemical in product per functional unit (e.g., $2.25 \mathrm{~kg}_{\text {flooring }} / \mathrm{m}^{2} \times 0.013 \%=$ $0.029 \mathrm{~kg}$ phenol in flooring $/ \mathrm{m}^{2}$ according to Table 2). This LCI flow constitutes an intuitive point of departure to determine product-related exposures. It can directly be multiplied by the $\mathrm{PiF}$ yielding the exposure to a chemical in a product per functional unit. Like $\mathrm{iF}, \mathrm{PiF}$ is compatible with the traditional LCIA (life cycle impact assessment) framework and can be multiplied by effect factors relating potential human health impacts to chemical exposure (e.g., in incidence risk $/ \mathrm{kg}_{\text {intake }}$ ) to determine characterization factors, i.e. human health impacts per mass of a chemical within a product (e.g., in incidence risk/ $\mathrm{kg}_{\text {in product }}$ ) used per FU. In this way, PiF facilitates a fair and consistent comparison of exposures to chemicals within or across a variety of products.

PiF also Enables Comparison between Different Life Cycle Stages. The use-stage PiF is directly comparable to the environmentally mediated $\mathrm{PiF}$ due to product disposal as both are calculated per unit chemical mass in product. Results for the various product-chemical combinations in Table 2 suggest that environmentally mediated exposures due to disposal are often orders of magnitude lower than the near-field use-stage exposures, but these exposures may also be of similar magnitude for bioaccumulative substances when the use-stage $\mathrm{PiF}$ is relatively low, for example SLES in shampoo. ${ }^{24}$ The comparison between life cycle stages could be extended to chemical emissions associated with upstream processes, for example, raw material extraction and product manufacturing, once LCI flows are combined with LCIA characterization, relating exposures and impacts across all life cycle stages to the same product FU.

Application in a Risk Assessment Context, As a Receptor-Oriented Approach. In RA, once a given chemical-product combination has been identified, for example, using one of the recently available chemical-product databases, ${ }^{12,13}$ exposure is characterized by assessing the daily chemical intake by the product user. To estimate daily exposures of consumers to chemicals in PCPs, we multiply $\mathrm{PiF}^{\text {use }}$ by the mass of PCP applied per person per day, the fraction of the chemical in the product, and normalize to the user's body weight, yielding for example a daily SLES intake of $1.7 \mathrm{~g}_{\mathrm{SLES} \text { intake }} / 70 \mathrm{~kg}_{\mathrm{BW}}=24 \mathrm{mg} / \mathrm{kg}_{\mathrm{BW}} / \mathrm{d}$ for an average body lotion application (Table 2). Such doses can be compared to reference doses ( $\mathrm{RfD}, \mathrm{mg} / \mathrm{kg}_{\mathrm{BW}} / \mathrm{d}$ ), acceptable daily intakes (ADI, $\mathrm{mg} / \mathrm{kg}_{\mathrm{BW}} / \mathrm{d}$ ), or to the minimum oral equivalency doses (OED, $\mathrm{mg} / \mathrm{kg}_{\mathrm{BW}} / \mathrm{d}$ ) as back-calculated from the U.S. Environmental Protection Agency's (EPA) ToxCast minimum bioactivity concentrations, $\mathrm{AC}_{50}{ }^{42}$ Taking flooring as another example for chemicals encapsulated in articles, the average flooring area per person can be used to relate the product to the user's exposure dose, but the relationship between product and exposed users is less direct to establish for such products. By default, the overall $\mathrm{PiF}$ has been defined as the intake integrated over the entire population. However, in a receptor-oriented approach like RA, it is necessary to differentiate the fractions taken in by various individuals; for example in the case of a PCP, the user is directly exposed, household members may be exposed through indoor air, and the general population is exposed via the fraction of chemicals washed out, transferred to wastewater treatment and subsequently emitted to the outdoor environment.

The average proportion between $\mathrm{PiF}^{\text {use }}$ and $\mathrm{PiF}^{\text {disposal }}$ remains valid when considering the aggregate cumulative exposure from an individual receptor perspective. The $\mathrm{PiF}^{\text {disposal }}$ associated with a single use is a sum of very small individual exposures distributed over the entire population, $N_{\text {pop }}$. When considering the $\mathrm{PiF}$ disposal for aggregate cumulative exposure from an individual receptor perspective $\left(P i F_{\text {individual cumulated }}^{\text {dispol }}\right)$ and assuming the entire population uses this same product, this small individual exposure is remultiplied by the entire population $\left(P i F_{\text {individual cumulated }}^{\text {dispol }}=N_{\text {pop }} \cdot P i F^{\text {disposal }} / N_{\text {pop }}=P i F^{\text {disposal }}\right)$ and on average each individual therefore receives the $\mathrm{PiF}^{\text {disposal }}$ in addition to their own $\mathrm{PiF}^{\text {use }}$.

In cases where the exact chemical content is unknown, a range of plausible concentrations may be provided based on the function of the chemical inside a product using databases like the European Commission's CosIng database, in conjunction with typical functional ranges from Frame formulations. ${ }^{43}$ Thus, there is a high need to establish typical functional ranges and to 
compose a list of appropriate sentinel products for various use classes, ${ }^{44}$ such as PCPs or cleaning agents. For an initial exposure risk screening of a given product class, the comparative capabilities of the $\mathrm{PiF}$ will support the identification of best suitable sentinel products, ${ }^{44}$ which are representative of a high-end exposure situation. Sentinel products can be identified as products which are used in large quantities while maintaining a high PiF. For example, for PCPs body lotion is suggested as a sentinel product due to long exposure durations and large quantities used.

In the absence of reliable concentration data, PiF may also be used to back-calculate a maximum acceptable fraction of a chemical within a product, $f_{c, \text { max }}$, from the $\mathrm{RfD}, \mathrm{ADI}$, or from the minimum OED, such that $f_{c, p \max }=R f D_{c} \times B W /\left(P i F_{c, p} \times\right.$ $\left.M_{p}\right)$ where BW is body weight $\left(\mathrm{kg}_{\mathrm{BW}}\right)$ and $M_{\mathrm{p}}$ is the daily mass of product applied $\left(\mathrm{kg}_{\text {product }} / \mathrm{d}\right)$. This maximum acceptable fraction can then be compared to plausible ranges of chemical concentrations in products. Applying this equation to Dlimonene for high-end body lotion users (reference dose of 5.5 $\left.\mathrm{mg} / \mathrm{kg}_{\mathrm{BW}} / \mathrm{d}\right){ }^{45}$ the back-calculated maximum concentration in body lotion amounts to $3.3 \%$, which is larger than the $0.5 \%$ indicated in Table 2, but still close to current maximum concentrations reported for $\mathrm{D}$-limonene in a product ingredient database $(0.1-2.5 \%) .^{12}$

Table 3 summarizes the main utility of the $\mathrm{PiF}$ metric indicating its key application modalities in different contexts.

\section{FINAL DISCUSSION AND OUTLOOK}

The product intake fraction is an important step in consistently analyzing consumer and population-scale exposure to chemicals in products. It uses the quantity of chemical inside a product as a point of departure, a readily measured or estimated parameter based on product composition. The presented examples illustrate how the $\mathrm{PiF}$ can be used for comparing chemical exposures in LCA and in RA contexts, to either determine intakes or to back-calculate maximum acceptable chemical content in products. Determining PiF will be a key element in characterizing and comparing consumer product exposure and making LCA fully suited for comparing the impacts of products on human health and for studying chemical substitution. Exposure estimates made in this manner also constitute important data which are complementary to high-throughput toxicology risk screening, such as the ToxCast data from the U.S. EPA. ${ }^{46}$ The PiF metric is especially well adapted for comparing direct or near-field applications, while allowing for a consistent usage of the intake fraction in case of environmentally mediated exposures.

When estimating PiF it is important to transparently provide assumptions and methods which are applicable to the product in question. For example, determining whether steady-state (e.g., SVOC releases from flooring or furniture) ${ }^{47}$ or dynamic modeling (e.g., pulse application of cosmetics) is best applicable.

The PiF depends on the reliability of the input data and nearand far-field models. Hence, there is a need for both more reliable exposure data and improved modeling of consumer product exposure pathways. Models are becoming increasingly available for indoor air environments and dermal application of cosmetics. ${ }^{8,48}$ Specific data and models need to be provided or refined to quantify the PiF for a larger number of productchemical combinations, for example for chemicals embedded in products like clothing and furniture, and for products used in enclosed environments like washing machines and dishwashers.
Further empirical data and research are especially needed to better understand poorly characterized exposure pathways, for example, material abrasion, food contact of packaging, and gaseous exchange between air and skin. ${ }^{49}$ For these challenging purposes, it is key to intensify knowledge sharing between industry, academia, and government agencies, building on the increasing amount of data made available via public disclosure of ingredients and product use assumptions. In this context, $\mathrm{PiF}$ as a comparative metric will help focusing data collection efforts on the most important parameters and product-chemical combinations.

Obtaining reliable data on plausible ranges in chemical content will be crucial and is under development for categories, such as PCPs and detergents, but will require substantial effort for the wider variety of products presently in use. For these, the use of the PiF to back-calculate maximum chemical content may be a very useful alternative to calculating exposure doses.

\section{AUTHOR INFORMATION}

\section{Corresponding Authors}

*(O.J.) Phone: +1-734-647-0394; fax: +1-734-763-8095; email: ojolliet@umich.edu.

*(P.F.) Phone: +45 452-544-52; fax: +45 459-334-35; e-mail: pefan@dtu.dk.

\section{Notes}

The authors declare no competing financial interest.

\section{Biography}

Dr. Olivier Jolliet is Professor in Impact and Risk Modeling in the Department of Environmental Health Sciences at the School of Public Health of the University of Michigan. His research and teaching focus on high throughput exposure screening, accounting for both far and near-field exposure, aiming (a) at assessing the life cycle risks and benefits of consumer products, food \& emerging technologies and (b) modeling population exposome, intake fractions and pharmacokinetics of emerging chemicals. He coinitiated the UNEP (United Nation Environment Programme)/SETAC Life Cycle Initiative.

Alexi Ernstoff was a researcher in the Impact and Risk Modeling laboratory at the University of Michigan and is currently a $\mathrm{PhD}$ candidate at the Division for Quantitative Sustainability Assessment of the Technical University of Denmark. Her research focuses on modeling human exposure to cosmetic and food products within high throughput screening and life cycle assessment.

Dr. Peter Fantke is Assistant Professor in the Division for Quantitative Sustainability Assessment at the Department of Management Engineering of the Technical University of Denmark. His research and teaching focus on assessing life cycle chemical emissions, far- and near-field exposures and impacts on humans and the environment, and evaluating alternatives to hazardous chemicals in products and systems. $\mathrm{He}$ is Managing Director of USEtox ${ }^{\circledR}$, the UNEP/SETAC scientific consensus model for assessing human toxicological and ecotoxicological impacts of chemical emissions.

Dr. Susan Csiszar has recently completed a Dow Postdoctoral Fellowship in Sustainability in the Department of Environmental Health Sciences at the School of Public Health of the University of Michigan. She is currently an Oak Ridge Institute for Science and Education (ORISE) Research Fellow hosted at the U.S. Environmental Protection Agency. Her research focuses on modeling near- and farfield sources, fate, transport, and subsequent exposures and impacts of chemicals of commerce with the ultimate goal of informing the sustainable use of chemicals. 


\section{ACKNOWLEDGMENTS}

This work has been supported by the Long-Range Research Initiative of the American Chemistry Council (MTH1001-01), the University of Michigan Risk Science Center, the Dow Postdoctoral Fellowship in Sustainability to SA Csiszar, and the Marie Curie project Quan-Tox (GA 631910) funded by the European Commission under the Seventh Framework Programme. We also thank Lei Huang for applying the Deng model to calculate releases from flooring materials.

\section{REFERENCES}

(1) Arnot, J. A.; Brown, T. N.; Wania, F.; Breivik, K.; McLachlan, M. $S$. Prioritizing chemicals and data requirements for screening-level exposure and risk assessment. Environ. Health Perspect. 2012, 120, $1565-1570$.

(2) Shin, H.-M.; McKone, T. E.; Bennett, D. H. Intake fraction for the indoor environment: A tool for prioritizing indoor chemical sources. Environ. Sci. Technol. 2012, 46, 10063-10072.

(3) Bare, J. C. Risk assessment and life-cycle impact assessment (LCIA) for human health cancerous and noncancerous emissions: Integrated and complementary with consistency within the USEPA. Hum. Ecol. Risk Assess. 2006, 12, 493-509.

(4) Olsen, S. I.; Christensen, F. M.; Hauschild, M.; Pedersen, F.; Larsen, H. F.; Tørsløv, J. Life cycle impact assessment and risk assessment of chemicals-A methodological comparison. Environ. Impact Assess. Rev. 2001, 21, 385-404.

(5) Lee, J.; Pedersen, A. B.; Thomsen, M. The influence of resource strategies on childhood phthalate exposure-The role of REACH in a zero waste society. Environ. Int. 2014, 73, 312-322.

(6) Crinnion, W. J. Toxic effects of the easily avoidable phthalates and parabens. Altern. Med. Rev. 2010, 15, 190-196.

(7) Lorber, M. Exposure of Americans to polybrominated diphenyl ethers. J. Exposure Sci. Environ. Epidemiol. 2008, 18, 2-19.

(8) Wenger, Y.; Li, D.; Jolliet, O. Indoor intake fraction considering surface sorption of air organic compounds for life cycle assessment. Int. J. Life Cycle Assess. 2012, 17, 919-931.

(9) Hellweg, S.; Demou, E.; Bruzzi, R.; Meijer, A.; Rosenbaum, R. K.; Huijbregts, M. A. J.; McKone, T. E. Integrating human indoor air pollutant exposure within life cycle impact assessment. Environ. Sci. Technol. 2009, 43, 1670-1679.

(10) Weschler, C. J.; Nazaroff, W. W. Semivolatile organic compounds in indoor environments. Atmos. Environ. 2008, 42, 9018-9040.

(11) Wambaugh, J. F.; Setzer, R. W.; Reif, D. M.; Gangwal, S.; Mitchell-Blackwood, J.; Arnot, J. A.; Jolliet, O.; Frame, A.; Rabinowitz, J.; Knudsen, T. B.; Judson, R. S.; Egeghy, P.; Vallero, D.; Cohen Hubal, E. A. High-throughput models for exposure-based chemical prioritization in the ExpoCast project. Environ. Sci. Technol. 2013, 47, 84798488.

(12) Goldsmith, M. R.; Grulke, C. M.; Brooks, R. D.; Transue, T. R.; Tan, Y. M.; Frame, A.; et al. Development of a consumer product ingredient database for chemical exposure screening and prioritization. Food Chem. Toxicol. 2014, 65, 269-279.

(13) Dionisio, K. L.; Frame, A. M.; Goldsmith, M. R.; Wambaugh, J. F.; Liddell, A.; Cathey, T.; Smith, D.; Vail, J.; Ernstoff, A. S.; Fantke, P.; Jolliet, O.; Judson, R. S. Exploring consumer exposure pathways and patterns of use for chemicals in the environment. Toxicol. Rep. 2015, 2, 228-237.

(14) Kuczenski, B.; Geyer, R.; Boughton, B. Tracking toxicants: Toward a life cycle aware risk assessment. Environ. Sci. Technol. 2011, $45,45-50$.

(15) Nazaroff, W.; Weschler, C. J.; Little, J. C.; Cohen Hubal, E. A. Intake to production ratio: A measure of exposure intimacy for manufactured chemicals. Environ. Health Perspect. 2012, 120, 16781683.
(16) Bennett, D. H.; McKone, T. E.; Evans, J. S.; Nazaroff, W. W.; Margni, M. D.; Jolliet, O.; Smith, K. R. Defining intake fraction. Environ. Sci. Technol. 2002, 36, 207A-211A.

(17) Kikuchi, Y.; Hirao, M. Practical method of assessing local and global impacts for risk-based decision making: A case study of metal degreasing processes. Environ. Sci. Technol. 2008, 42, 4527-4533.

(18) Hellweg, S.; Demou, E.; Scheringer, M.; McKone, T. E.; Hungerbühler, K. Confronting workplace exposure to chemicals with LCA: Examples of trichloroethylene and perchloroethylene in metal degreasing and dry cleaning. Environ. Sci. Technol. 2005, 39, 77417748.

(19) Fantke, P.; Juraske, R.; Antón, A.; Friedrich, R.; Jolliet, O. Dynamic multicrop model to characterize impacts of pesticides in food. Environ. Sci. Technol. 2011, 45, 8842-8849.

(20) Fantke, P.; Friedrich, R.; Jolliet, O. Health impact and damage cost assessment of pesticides in Europe. Environ. Int. 2012, 49, 9-17.

(21) Fantke, P.; Jolliet, O. Life cycle human health impacts of 875 pesticides. Int. J. Life Cycle Assess. 2015, DOI: 10.1007/s11367-0150910-y.

(22) Little, J. C.; Weschler, C. J.; Nazaroff, W. W.; Liu, Z.; Cohen Hubal, E. A. Rapid methods to estimate potential exposure to semivolatile organic compounds in the indoor environment. Environ. Sci. Technol. 2012, 46, 11171-11178.

(23) Nazaroff, W. W.; Weschler, C. J. Cleaning products and air fresheners: Exposure to primary and secondary air pollutants. Atmos. Environ. 2004, 38, 2841-2865.

(24) Ernstoff, A. S.; Fantke, P.; Csiszar, S. A.; Henderson, A. D.; Chung, S.; Jolliet, O. Modeling exposure to chemicals in cosmetics for life cycle and screening assessments: A shampoo case study. Environ. Sci. Technol. 2015, submitted.

(25) U.S. EPA. Estimation Programs Interface SuiteTM for Microsoft ${ }^{\circledR}$ Windows, v 4.11; United States Environmental Protection Agency, 2012.

(26) Rosenbaum, R. K.; Bachmann, T. M.; Gold, L. S.; Huijbregts, M. A. J.; Jolliet, O.; Juraske, R.; Koehler, A.; Larsen, H. F.; MacLeod, M.; Margni, M. D.; McKone, T. E.; Payet, J.; Schuhmacher, M.; van de Meent, D.; Hauschild, M. Z. USEtox - The UNEP-SETAC toxicity model: Recommended characterisation factors for human toxicity and freshwater ecotoxicity in life cycle impact assessment. Int. J. Life Cycle Assess. 2008, 13, 532-546.

(27) Csiszar, S.; Ernstoff, A.; Fantke, P.; Jolliet, O. Stochastic modeling of near-field exposure to parabens in personal care products. J. Exposure Sci. Environ. Epidemiol. 2015, submitted.

(28) Deng, B.; Kim, C. N. An analytical model for VOCs emission from dry building materials. Atmos. Environ. 2004, 38, 1173-1180.

(29) Webster, T. F.; Harrad, S.; Millette, J. R.; Holbrook, R. D.; Davis, J. M.; Stapleton, H. M.; Allen, J. G.; McClean, M. D.; Ibarra, C.; Abdallah, M. A.-E.; Covaci, A. Identifying transfer mechanisms and sources of decabromodiphenyl ether (BDE 209) in indoor environments using environmental forensic microscopy. Environ. Sci. Technol. 2009, 43, 3067-3072.

(30) Weschler, C. J.; Nazaroff, W. W. SVOC exposure indoors: Fresh look at dermal pathways. Indoor Air 2012, 22, 356-377.

(31) ten Berge, W. A simple dermal absorption model: Derivation and application. Chemosphere 2009, 75, 1440-1445.

(32) Bouma, K.; Schakel, D. J. Migration of phthalates from PVC toys into saliva simulant by dynamic extraction. Food Addit. Contam. 2002, 19, 602-610.

(33) Bremmer, H. J.; van Veen, M. P. Children's toys fact sheet. In To Assess the Risks for the Consumer, RIVM report 612810012/2002; Bilthoven, The Netherlands, 2002.

(34) Niino, T.; Ishibashi, T.; Itoh, T.; Sakai, S.; Ishiwata, H.; Yamada, T.; Onodera, S. Comparison of diisononyl phthalate migration from polyvinyl chloride products into human saliva in vivo and into saliva simulant in vitro. J. Health Sci. 2002, 48, 277-281.

(35) Babich, M. A.; Chen, S.-B.; Greene, M. A.; Kiss, C. T.; Porter, W. K.; Smith, T. P.; Wind, M. L.; Zamula, W. W. Risk assessment of oral exposure to diisononyl phthalate from children's products. Regul. Toxicol. Pharmacol. 2004, 40, 151-167. 
(36) Bauer, M. J.; Herrmann, R. Estimation of the environmental contamination by phthalic acid esters leaching from household wastes. Sci. Total Environ. 1997, 208, 49-57.

(37) Goedkoop, M.; Heijungs, R.; Huijbregts, M.; De Schryver, A.; Struijs, J.; van Zelm, R. ReCiPe 2008: A Life Cycle Impact Assessment Method Which Comprises Harmonised Category Indicators at the Midpoint and the Endpoint Level, First edition Report I: Characterisation, 2009.

(38) U.S. EPA Tool for the Reduction and Assessment of Chemical and Other Environmental Impacts (TRACI): User's Guide and System Documentation; United States Environmental Protection Agency: Cincinnati, Ohio, 2003.

(39) Jolliet, O.; Margni, M. D.; Charles, R.; Humbert, S.; Payet, J.; Rebitzer, G.; Rosenbaum, R. K. IMPACT 2002+: A new life cycle impact assessment methodology. Int. J. Life Cycle Assess. 2003, 8, 324330.

(40) McKone, T. E. CalTOX, A Multimedia Total Exposure Model for Hazardous-Waste Sites, Part 1: Executive Summary, UCRL-CR111456-Pt.1; Livermore, CA, 1993.

(41) Hauschild, M. Z.; Goedkoop, M.; Guinée, J.; Heijungs, R.; Huijbregts, M.; Jolliet, O.; Margni, M.; De Schryver, A.; Humbert, S.; Laurent, A.; Sala, S.; Pant, R. Identifying best existing practice for characterization modeling in life cycle impact assessment. Int. J. Life Cycle Assess. 2013, 18, 683-697.

(42) Wetmore, B. A.; Wambaugh, J. F.; Ferguson, S. S.; Sochaski, M. A.; Rotroff, D. M.; Freeman, K.; Clewell, H. J.; Dix, D. J.; Andersen, M. E.; Houck, K. A.; Allen, B.; Judson, R. S.; Singh, R.; Kavlock, R. J.; Richard, A. M.; Thomas, R. S. Integration of dosimetry, exposure, and high-throughput screening data in chemical toxicity assessment. Toxicol. Sci. 2012, 125, 157-174.

(43) Heinemeyer, G.; Hahn, A. Use of product databases for risk assessment purposes. Toxicol. Appl. Pharmacol. 2005, 207, 636-644.

(44) Jayjock, M. A.; Chaisson, C. F.; Franklin, C. A.; Arnold, S.; Price, P. S. Using publicly available information to create exposure and riskbased ranking of chemicals used in the workplace and consumer products. J. Exposure Sci. Environ. Epidemiol. 2008, 19, 515-524.

(45) Kim, Y. W.; Kim, M. J.; Chung, B. Y.; Bang, D. Y.; Lim, S. K.; Choi, S. M.; Lim, D. S.; Cho, M. C.; Yoon, K.; Kim, H. S.; Kim, K. B.; Kim, Y. S.; Kwack, S. J.; Lee, B.-M. Safety evaluation and risk assessment of D-limonene. J. Toxicol. Environ. Health 2013, 16, 17-38.

(46) Kavlock, R.; Chandler, K.; Houck, K.; Hunter, S.; Judson, R.; Kleinstreuer, N.; Knudsen, T.; Martin, M.; Padilla, S.; Reif, D.; Richard, A.; Rotroff, D.; Sipes, N.; Dix, D. Update on EPA's ToxCast program: Providing high throughput decision support tools for chemical risk management. Chem. Res. Toxicol. 2012, 25, 1287-1302.

(47) Alcock, R. E.; Sweetman, A. J.; Prevedouros, K.; Jones, K. C. Understanding levels and trends of BDE-47 in the UK and North America: An assessment of principal reservoirs and source inputs. Environ. Int. 2003, 29, 691-698.

(48) Tibaldi, R.; ten Berge, W.; Drolet, D. Dermal absorption of chemicals: Estimation by IH SkinPerm. J. Occup. Environ. Hyg. 2014, $11,19-31$.

(49) Weschler, C. J.; Nazaroff, W. W. Dermal uptake of organic vapors commonly found in indoor air. Environ. Sci. Technol. 2014, 48, $1230-1237$. 